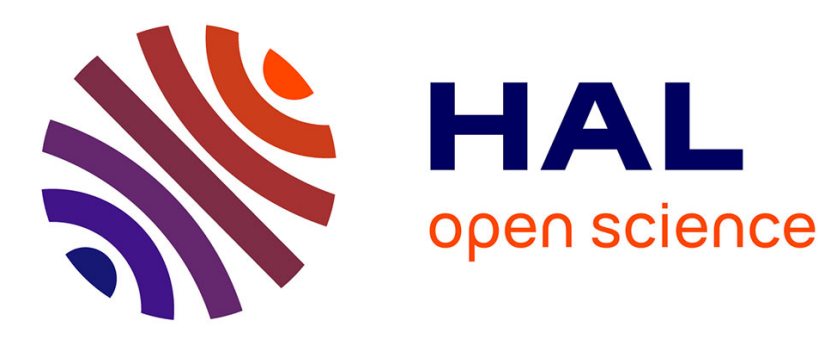

\title{
Linear viscoelasticity of hot-pressed hybrid poplar relates to densification and to the in situ molecular parameters of cellulose
}

Isabela Reiniati, Noridah B. Osman, Armando G. Mc Donald, Marie-Pierre Laborie

\section{To cite this version:}

Isabela Reiniati, Noridah B. Osman, Armando G. Mc Donald, Marie-Pierre Laborie. Linear viscoelasticity of hot-pressed hybrid poplar relates to densification and to the in situ molecular parameters of cellulose. Annals of Forest Science, 2015, 72 (6), pp.693-703. 10.1007/s13595-014-0421-1 . hal01284204

\section{HAL Id: hal-01284204 \\ https://hal.science/hal-01284204}

Submitted on 7 Mar 2016

HAL is a multi-disciplinary open access archive for the deposit and dissemination of scientific research documents, whether they are published or not. The documents may come from teaching and research institutions in France or abroad, or from public or private research centers.
L'archive ouverte pluridisciplinaire HAL, est destinée au dépôt et à la diffusion de documents scientifiques de niveau recherche, publiés ou non, émanant des établissements d'enseignement et de recherche français ou étrangers, des laboratoires publics ou privés. 


\title{
Linear viscoelasticity of hot-pressed hybrid poplar relates to densification and to the in situ molecular parameters of cellulose
}

\author{
Isabela Reiniati • Noridah B. Osman • Armando G. Mc Donald • \\ Marie-Pierre Laborie
}

Received: 7 May 2014 / Accepted: 8 September 2014 / Published online: 1 October 2014

(C) INRA and Springer-Verlag France 2014

\begin{abstract}
- Key message Hot pressing leads to changes in wood water sorption properties, linear viscoelastic behavior, and chemistry. In hot-pressed hybrid poplar, storage modulus linearly correlates with cellulose apparent crystallinity index and degree of polymerization, revealing the impact of cellulose hydrolysis on wood viscoelasticity during hot pressing.

- Context Heat treatment and densification during hot pressing are known to alter wood chemical, physical, and viscoelastic properties. Interrelationships between these properties and their changes during hot pressing are, however, unknown. They are expected to play a significant role on mat consolidation during the manufacture of wood-based composites.
\end{abstract}

\section{Handling Editor: Jean-Michel Leban}

Contribution of the co-authors I. Reiniati performed all experimental work concerning physical and viscoelastic properties and their interpretation and cowrote the manuscript. N. Osman performed all experiments on chemical analyses of cellulose and analyzed these data. A. Mc Donald supervised the work on chemical analysis and participated in data analysis and interpretation and cowrote the section on chemical analyses. M-P Laborie supervised the work on physico-viscoelastic analyses and participated in data interpretation and paper writing as well as coordinating the project. Armando McDonald and M.-P. Laborie conceived the project and designed the experiments to test the hypotheses.

\section{Reiniati}

University of Western Ontario, London, Canada

e-mail: ireiniat@uwo.ca

N. B. Osman

Universiti Teknologi Petronas, Tronoh, Malaysia

e-mail: noridah.osman@petronas.com.my

\section{A. G. Mc Donald}

Department of Forest, Rangeland and Fire Sciences, College of Natural Resources, University of Idaho, Moscow, USA

e-mail: armandm@uidaho.edu
- Aims This study aims (1) to characterize the impact of hot pressing on the physical, viscoelastic, and chemical properties of hybrid-poplar wood and (2) to assess possible relationships between these properties.

- Methods Dry and moist wood samples were hot-pressed under various conditions of temperature. Specific gravity, water sorption isotherms, and dynamic viscoelastic properties of hot-pressed wood were measured together with cellulose apparent crystallinity and molecular weight. Possible relationships between these properties were assessed with statistical analyses.

- Results Wood specific gravity, sorption isotherm, dynamic moduli, and cellulose crystallinity were all affected by the hotpressing conditions. The viscoelastic response of hot-pressed wood was found to relate not only to the extent of densification but also to in situ molecular properties of cellulose. Cellulose apparent crystallinity index and degree of polymerization in hot-pressed wood linearly correlated with storage modulus, revealing the importance of cellulose hydrolysis during hot pressing on wood viscoelastic response.

- Conclusion During hot pressing, wood cellulose hydrolysis appears to govern the viscoelastic response, in addition to wood densification.

Keywords Wood viscoelasticity $\cdot$ Specific properties $\cdot$ Wood polymer morphology $\cdot$ Hot pressing $\cdot$ Cellulose crystallinity . Cellulose depolymerization

M.-P. Laborie ( $\square)$

Forest Biomaterials, University of Freiburg, Werthmanstr.6, 79085 Freiburg, Germany

e-mail: marie-pierre.laborie@fobawi.uni-freiburg.de 


\section{Introduction}

In the wood industry, heat treatment has long been used to enhance various wood properties such as dimensional stability, density, and fungal resistance. Subjecting wood to high temperatures alters its chemistry as first evidenced by its weight loss (Kotilainen et al. 1999; Reinprecht et al. 1999; Hakkou et al. 2005a; Yildiz et al. 2005; Repellin and Guyonnet 2005; Boonstra et al. 2006). Kotilainen et al. (1999) investigated the changes in the chemical composition of Norway spruce and reported that mass loss was highly dependent on treatment temperature, with significant degradation occurring above $220{ }^{\circ} \mathrm{C}$. Hemicelluloses, in particular galactoglucomannans and arabinoglucoronoxylans, were found to degrade first and to contribute most to wood mass loss (Tjeerdsma et al. 1998; Kotilainen et al. 1999, 2001). Navi and Heger (2004) reported the start of hemicellulose degradation with arabinose, galactose, mannose, and xylose at 180 and $200{ }^{\circ} \mathrm{C}$ in steamed, hot-pressed wood. Acetic acid, furfural, and formaldehyde form upon decomposition (Tjeerdsma et al. 1998). Thermal treatment affects lignin and cellulose as well. Osman et al. $(2012,2013)$ observed an increase in the dichloromethane extractive content $(9 \%)$ in hot-pressed poplar around $250{ }^{\circ} \mathrm{C}$, which mainly comprised solubilized lignin. Reduction of lignin molecular weight was induced by lignin depolymerization. Tjeerdsma et al. (1998) hypothesized that heat treatment of wood enhances the demethoxylation of guaiacyl and syringyl units in lignin, thereby increasing the amount of reactive hydroxyl lignin sites. They also proposed that cross-linking of these free phenolic units with furfural compounds and acetic acid creates a more rigid structure around cellulose microfibrils, thereby hindering water penetration in the cell wall. This mechanism may be responsible for the improvement in the dimensional stability of heat-treated wood. Ito et al. (1998) postulated that semicrystalline cellulose is disturbed and damaged during compressive deformation, allowing the release of cellulose microfibrils' inner stress. Steam facilitates the rearrangement of the cellulose chains, which can form additional crystalline regions (Ito et al. 1998; Bhuyian et al. 2000). In addition, conformational changes in polysaccharides due to water desorption (Hakkou et al. 2005b) and crystallization of amorphous regions were proposed to increase the cellulose crystallinity (Akgúl et al. 2007). Hydrolysis of amorphous cellulose has also been reported and results in higher crystallinity index of cellulose in hydrothermally treated wood (Silva et al. 2013; Xiao et al. 2014). As a result, heat-treated wood exhibits improved dimensional stability and decreased hygroscopicity; for example, heat-treated wood conditioned at $96 \%$ relative humidity experiences a moisture content decrease from $30 \%$ to roughly $10 \%$ but only a minor reduction of strength. However, depending on conditions, heat treatment of wood can increase or decrease mechanical properties. In general, heat treatment increases stiffness but reduces strength. Korkut et al. (2008) demonstrated that compression strength, bending strength, and modulus of elasticity are reduced by heat treatment above a certain temperature. Treating wood at $120{ }^{\circ} \mathrm{C}$ for $2 \mathrm{~h}$ does not significantly affect these properties.

During hot pressing, similar chemical changes might be expected and complicated by the combined action of pressure and densification. Indeed, compression can either fracture cell walls or allow viscoelastic and plastic deformation, depending on wood polymers' viscoelastic behavior under the compression conditions (Navi and Girardet 2000; Penneru et al. 2006). In particular, at high hot-pressing temperatures and wood moisture contents, densification of wood can intensify due to the higher deformability of wood polymers and higher level of cell wall fracture (Tabarsa and Chui 1997). Only one study reports on the chemical changes caused by hot pressing in conditions relevant to the manufacture of wood-based composites (Gardner et al. 1993). This study suggests that the increased mobility of wood amorphous polymers and the expansion of free volume above lignin glass transition temperature $\left(T_{\mathrm{g}}\right)$ allow the reorientation of the hydrophobic functionalities of amorphous polymers toward the surface. Enhanced crystallization of cellulose at temperatures near lignin $T_{\mathrm{g}}$ was also proposed (Gardner et al. 1993).

Overall, during hot pressing, heat-induced chemical, physical, and viscoelastic changes of wood all likely contribute to its response to hot pressing. However, little is known of the possible interdependences between chemical, physical, and viscoelastic changes during hot pressing. In particular, the impact of hot pressing on wood viscoelastic properties and the interrelationships between wood chemical changes and wood viscoelasticity, which are critical to mat consolidation, are not known. We hypothesize that changes in wood viscoelasticity might relate to changes in wood molecular structure. Hybrid poplars represent an alternative resource for wood-based composites and are well suited to shed light on such behavior, as they might be improved for composite manufacture.

\section{Objectives}

The overall goal of this work is to investigate the effect of hotpressing conditions on the chemical, physical, and viscoelastic 
properties of hybrid poplar wood. The specific objectives of this study are (1) to understand the impact and possible interactions of wood initial moisture content and hot-pressing temperature on wood morphology, specific gravity, and bending dynamic mechanical properties and (2) to unravel some of the molecular origins for changes in physical and viscoelastic properties.

\section{Materials and methods}

\subsection{Sample preparation and hot-pressing treatments}

A green hybrid poplar log (clone OP-367) supplied by Potlatch Corp. was sliced into flat sawn veneers. The bottom part of the log was divided into three sections (top, middle, and bottom), from which four sets of eight veneers, in nominal dimension of $100 \times 100 \times 2.3 \mathrm{~mm}^{3}$, were randomly sampled. After drying under high vacuum at room temperature, wood samples were either stored in a desiccator with $\mathrm{CaSO}_{4}$ or placed in $65 \%$ relative humidity. An experimental plan was designed to test the impact of wood initial moisture content ( 0 and $9 \%$ ), hot-pressing temperature $\left(150,200\right.$, and $\left.250{ }^{\circ} \mathrm{C}\right)$, and their interaction (Table 1). The veneers were hot-pressed in a $46 \times 46-\mathrm{cm}^{2}$ Wabash hot press of $3.4 \mathrm{MPa}$ for $5 \mathrm{~min}$. Upon hot pressing, sample thickness was reduced to approximately $1.0 \mathrm{~mm}$. Control specimens were also prepared.

\subsection{Cellulose analysis}

In situ cellulose relative crystallinity was monitored with Fourier transform infrared (FTIR) spectroscopy. In addition, cellulose was extracted from the wood samples and characterized for molecular weight by gel permeation chromatography (GPC). FTIR was performed in triplicate on wood samples using an Avatar 370 spectrometer (Thermo Nicolet) in the

Table 1 Hot-pressing conditions and resulting densification including average specific gravity for control and hot-pressed hybrid poplar samples

\begin{tabular}{|c|c|c|c|c|}
\hline & $\begin{array}{l}\text { Wood } \\
\text { moisture } \\
\text { content } \\
(\%)\end{array}$ & $\begin{array}{l}\text { Pressing } \\
\text { temperature } \\
\left({ }^{\circ} \mathrm{C}\right)\end{array}$ & $\begin{array}{l}\text { Oven-dry } \\
\text { specific gravity } \\
\left(\mathrm{SG}_{0, \mathrm{OD}}\right)\end{array}$ & $\begin{array}{l}\% \text { densification } \\
=\left(\mathrm{SG}_{\text {after }}-\right. \\
\left.\mathrm{SG}_{\text {before }}\right) / \\
\mathrm{SG}_{\text {before }} * 100\end{array}$ \\
\hline Control & - & - & $0.35 \pm 0.03 \mathrm{C}$ & - \\
\hline $9 \%, 150{ }^{\circ} \mathrm{C}$ & 9 & 150 & $0.90 \pm 0.06 \mathrm{~A}$ & 154 \\
\hline $9 \%, 200{ }^{\circ} \mathrm{C}$ & 9 & 200 & $0.90 \pm 0.06 \mathrm{~A}$ & 153 \\
\hline $9 \%, 250{ }^{\circ} \mathrm{C}$ & 9 & 250 & $0.80 \pm 0.10 \mathrm{~A}, \mathrm{~B}$ & 132 \\
\hline $0 \%, 150{ }^{\circ} \mathrm{C}$ & 0 & 150 & $0.64 \pm 0.16 \mathrm{~B}$ & 81 \\
\hline $0 \%, 200{ }^{\circ} \mathrm{C}$ & 0 & 200 & $0.85 \pm 0.12 \mathrm{~A}$ & 141 \\
\hline $0 \%, 250{ }^{\circ} \mathrm{C}$ & 0 & 250 & $0.80 \pm 0.05 \mathrm{~A}, \mathrm{~B}$ & 124 \\
\hline
\end{tabular}

Letters represent Tukey-Kramer grouping attenuated total reflectance (ATR) mode (single-bounce ZnSe, Smart Performer). The spectra were averaged, corrected (ATR and baseline) using the Omnic v7 software (Thermo Scientific), and analyzed with curve (peak) fitted to separate overlapping bands in specific spectral regions using the IGOR Pro 6.03 (WaveMetrics, Inc.) software. Cellulose crystallinity was determined using both the relative band heights of $1,429 / 897 \mathrm{~cm}^{-1}$ (Akerholm et al. 2004) and relative band areas of 1,375/ $2,900 \mathrm{~cm}^{-1}$ (Nelson and O'Connor 1964a, b). For molecular weight analysis of cellulose, extractive-free wood (Osman et al. 2012) was first delignified using $\mathrm{NaClO}_{2}$ to form holocellulose (Wise et al. 1946). The holocellulose samples $(20 \mathrm{mg})$ were derivatized to their tricarbanilate form on reaction with phenylisocyanate in pyridine at $80{ }^{\circ} \mathrm{C}$ for $48 \mathrm{~h}$ and isolated after precipitation with $30 \%$ aqueous methanol (Suckling et al. 2001). Separation was performed on Jordi Gel DVB Mixed Bed and 500-Á columns at $40{ }^{\circ} \mathrm{C}$ on elution with $\mathrm{THF}$ $\left(0.5 \mathrm{ml} \mathrm{min}^{-1}\right)$ with refractive index (Waters 2478) and rightand low-angle laser light scattering and differential viscometer detection (Viscotek model 270). Data were collected and analyzed using the OmniSEC v4.1 software (Viscotek). The weight-average degree of polymerization $\left(D P_{\mathrm{w}}\right)$ was calculated by dividing the weight-average molecular weight $\left(M_{\mathrm{w}}\right)$ to the tricarbanilate glucosyl repeat unit $\left(519 \mathrm{~g} \mathrm{~mol}^{-1}\right)$.

\subsection{Specific gravity measurement}

Specific gravity $\left(S G_{0, \mathrm{OD}}\right)$ and extent of densification were determined on oven-dry samples according to ASTM D 2395-07:

$S G_{0, O D}=\frac{\text { weight }_{\text {ovendry }}}{\text { volume }_{\text {ovendry }}}$

Nominal dimensions were $50 \mathrm{~mm}$ along the grain and $12 \mathrm{~mm}$ wide with a thickness of $2.3 \mathrm{~mm}$. The degree of densification (\%) was calculated from the difference in $S G_{0, \text { OD }}$ for control (before) and hot-pressed (after) hybrid poplar samples according to (2):

Densification $(\%)=\frac{S G_{0, \mathrm{OD}, \text { after }}-S G_{0, \mathrm{OD}, \text { before }}}{S G_{0, \mathrm{OD}, \text { before }}} * 100 \%$

3.4 Characterization of wood viscoelastic properties by dynamic mechanical analysis

Samples, $50 \mathrm{~mm} \times 12 \mathrm{~mm} \times 2.3 \mathrm{~mm}^{3}$ (for control samples) or ca. $2 \mathrm{~mm}$ in thickness (for hot-pressed samples), were tested along the grain in 3-point bending mode on a Tritec 2000 DMA Instrument. Before testing, the samples were freeze dried to less than $0.7 \%$ moisture content under vacuum and kept in a vacuum desiccator with $\mathrm{P}_{2} \mathrm{O}_{5}$ until use. DMA was 
performed in the linear viscoelastic range, as determined by strain scans at room temperature and at $120^{\circ} \mathrm{C}$. After cooling to $25 \pm 2{ }^{\circ} \mathrm{C}$ with liquid nitrogen at ca. $5{ }^{\circ} \mathrm{C} \mathrm{min}{ }^{-1}$, a temperature scan was performed from 30 to $120^{\circ} \mathrm{C}$ at $1 \mathrm{~Hz}$ and at a heating rate of $2{ }^{\circ} \mathrm{C} \mathrm{min}^{-1}$.

\subsection{Sorption tests}

At least 12 specimens were machined from each veneer groups to $50 \times 12 \mathrm{~mm}^{2}$ and subsequently freeze-dried to $\sim 0.7 \%$ moisture content. These samples were placed in a humidity chamber (G-64 Elite, Russells Technical Products) at $20 \pm 1{ }^{\circ} \mathrm{C}$ and $30 \pm 1 \%$ relative humidity (RH). The moisture uptake was gravimetrically measured daily with a 0.0001-g accuracy balance until weight stabilized to the equilibrium moisture content (EMC). The chamber RH was then increased to $45 \%$ and moisture uptake measured again. The procedure was repeated for RH of $60 \pm 1,80 \pm 1$, and $90 \pm 1 \%$. Generally, the equilibrium condition was achieved after approximately 5 to 10 days of conditioning. Wood EMC (\%) was calculated based on final mass $\left(m_{\text {wet }}\right)$ and freeze-dried mass $\left(m_{\text {dry }}\right)$ as (3):

$$
\operatorname{EMC}(\%)=\frac{m_{\mathrm{wet}}-m_{\mathrm{dry}}}{m_{\mathrm{dry}}}
$$

Adsorption isotherms were then constructed by plotting the EMC corresponding to each $\mathrm{RH}$ at $20^{\circ} \mathrm{C}$.

\subsection{Statistical analyses}

As there is a well-established correlation between wood mechanical properties and density of wood, all measured properties were first tested for dependency on specific gravity via simple linear regression. When such a dependency was observed, an analysis of covariance (ANCOVA) using specific gravity as a covariate was performed at an $\alpha$ level of 0.05 using SAS 9.1 statistical software to reveal significant differences independently of density effects. Properties of interest were also normalized to specific gravity, leading to specific properties. For example, the storage modulus of a wood sample divided by its specific gravity defines the specific storage modulus of that sample. All specific properties were analyzed with ANOVA followed by a Tukey-Kramer post hoc analysis when significant differences had been detected. Specific gravity, storage and loss moduli at 3 and $120{ }^{\circ} \mathrm{C}$, relative modulus drop between these temperatures, and peak temperature observed on the loss modulus thermogram were considered for these analyses.

\section{Results}

\subsection{Effect of hot pressing on cellulose in situ chemistry}

FTIR spectra of control and $9 \%$ moisture content (MC) hot-pressed poplar are shown in Fig. 1a. The celluloseassigned bands at $897 \mathrm{~cm}^{-1}$ (asymmetric out-of-phase ring stretch in the $\mathrm{C}_{1}-\mathrm{O}-\mathrm{C}_{4}$ glycosidic linkage), $1,375 \mathrm{~cm}^{-1}$ (C-H bending), $1,429 \mathrm{~cm}^{-1}$ (C-H wagging), and $2,900 \mathrm{~cm}^{-1}$ (C-H stretching) were shown to change upon hot pressing, indicating changes in cellulose (Nelson and O'Connor 1964a, b). To correctly resolve, assign, and quantify overlapping bands, curve fitting was applied (Fig. 1b). In situ cellulose crystallinity was assessed by FTIR spectroscopy using two methods: (i) lateral order index (LOI) from ratios of band heights $H_{1,429} / H_{897}$ (Akerholm et al. 2004) and (ii) total crystalline index (TCI) from ratios of band areas $A_{1,375} / A_{2900}$ (Nelson and O'Connor 1964a, b). For the LOI method, band height values were used based on findings by Akerholm et al. (2004), Carrillo et al. (2004), and Yildiz and Gumuskaya (2007). The results are given in Table 2. The band height ratios of $H_{1,429} / H_{897}$ of the hot-pressed group at 0 and $9 \%$ at $200{ }^{\circ} \mathrm{C}$, as well as at $0 \%$ and $150{ }^{\circ} \mathrm{C}$, were the same as those of the control group, indicating no change in crystallinity. This ratio significantly increased when wood was hot-pressed at the highest temperature of $250{ }^{\circ} \mathrm{C}$, especially for wood with $9 \%$ MC. The band increase suggested that at $250{ }^{\circ} \mathrm{C}$, cellulose underwent further crystallization, especially when moisture was present (Table 2). While this crystallinity increase remained small, the increase was consistent with treatment severity. The increase in crystallinity was attributed to the reduction in the amorphous region by crystallization of amorphous cellulose induced by hot pressing, in particular, under the plasticizing action of water (Bhuyian et al. 2000; Xiao et al. 2014). For the TCI method, band area was used after peak fitting, and this resulted in a better fit than using band height. TCI was also significantly affected by hot pressing $(p<0.0001)$ (Table 2$)$ above $200{ }^{\circ} \mathrm{C}$.

Additionally, the effect of hot pressing on cellulose $D P_{\mathrm{w}}$ was assessed from GPC of the extracted and tricarbanilated holocellulose. The low $D P_{\mathrm{w}}$ value of 1,033 of the control poplar sample compared to red maple (Schroeder and Haigh 1979) and aspen (Laka and Chernyavskaya 2007) suggested significant degradation of cellulose during delignification, as observed with chlorite treatment by others (Cael et al. 1980). Still, this analysis allowed evidencing the trend of decreasing cellulose molecular weight with hot-pressing severity (Table 2) in agreement with previous studies on birch and aspen (Laka and Chernyavskaya 2007). For molecular weight, temperature appeared to be the most significant factor, while initial MC had no impact. 
Fig. 1 a FTIR spectra for control and hot-pressed poplar ( $9 \% \mathrm{MC})$ samples and $\mathbf{b}$ expanded spectral region of hot-pressed poplar at $250{ }^{\circ} \mathrm{C}$ and $9 \% \mathrm{MC}$ showing curve fitting of bands

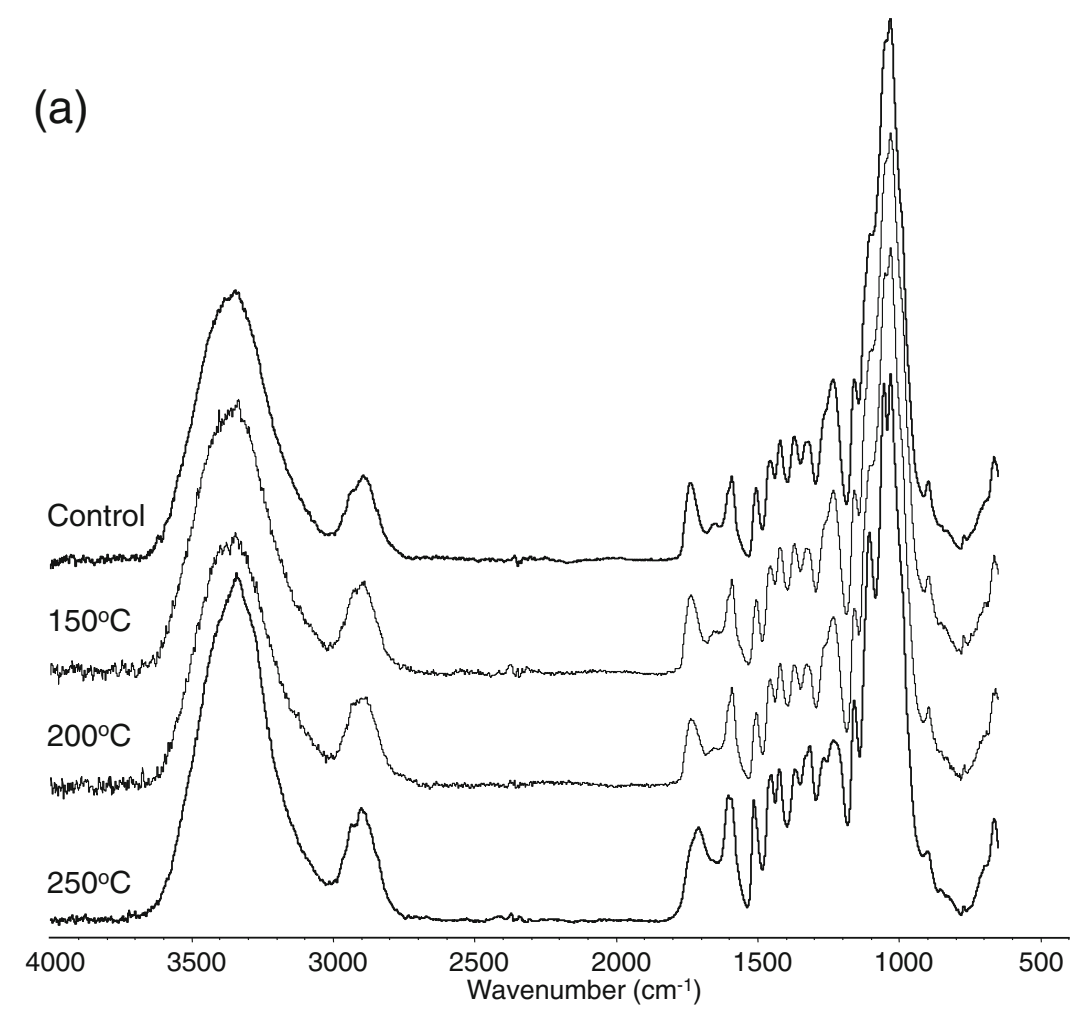

(b)

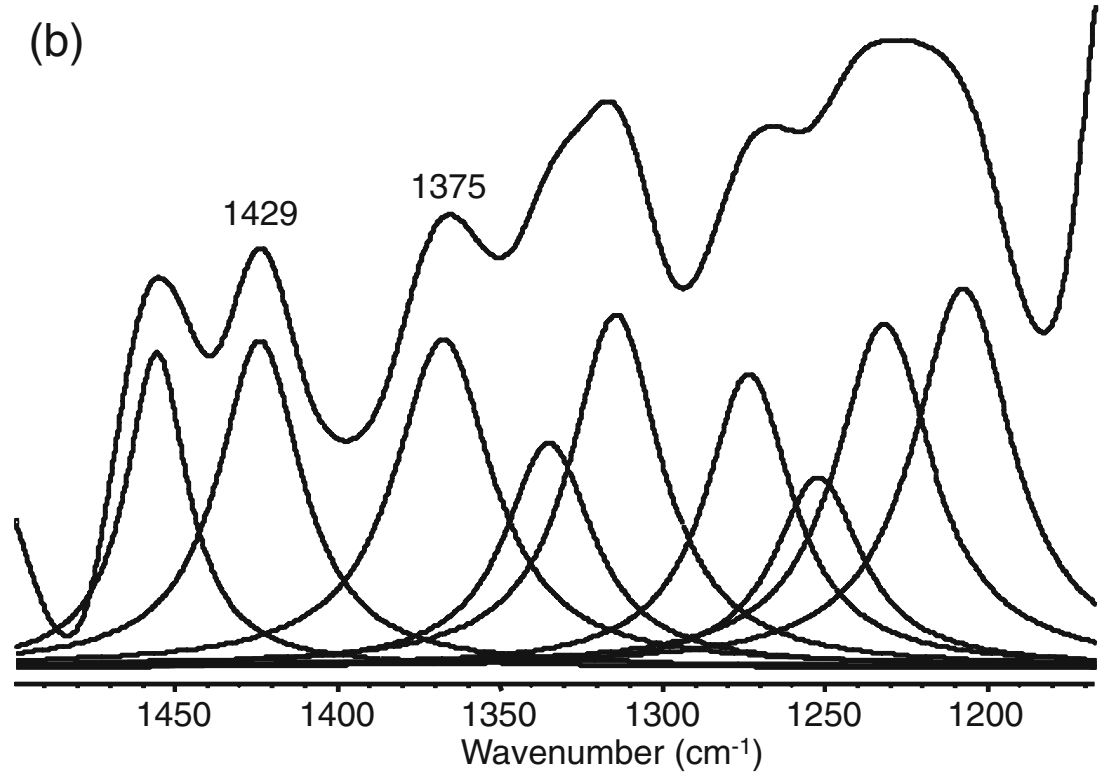

4.2 Effect of hot pressing on wood physical properties: specific gravity and water adsorption behavior

Untreated poplar samples had an average specific gravity (SG) of $0.35 \pm 0.03$; it increased twofold to threefold upon hot pressing, reaching values of $0.64 \pm 0.16$ to $0.90 \pm 0.06 \mathrm{SG}$ range $(p$ value $=0.0001)$. Based on Tukey-Kramer analysis, distinct increases in SG were evidenced for the different hotpressing conditions. All hot-pressed samples pertained to the same A grouping, except for that hot-pressed at $0 \%$ at $150{ }^{\circ} \mathrm{C}$, which experienced a smaller increase in $\mathrm{SG}$ (group B) (Table 3 and Fig. 2). On average, moist samples experienced a higher densification level than dry samples, as expected from water plasticizing effect on wood polymers. During hot pressing, the steam generated from wood moisture further mobilizes the cell wall polymers thus enhancing densification (Wolcott et al. 1990). High-pressure steam pretreatment is also known to cause partial hydrolysis of hemicelluloses resulting 
Table 2 Cellulose crystallinity (TCI and LOI) and $D P_{\mathrm{w}}$ of hot-pressed poplar

\begin{tabular}{lllr}
\hline Treatment & $\begin{array}{l}\text { TCI method } \\
A_{1,375} / A_{2,900}\end{array}$ & $\begin{array}{l}\text { LOI method } \\
H_{1,429} / H_{898}\end{array}$ & \multicolumn{1}{l}{$D P_{\mathrm{w}}$} \\
\hline Control & $0.4013(0.0247)$ & $1.598(0.035)$ & $1,033(0.2)$ \\
$9 \% \mathrm{MC}, 150{ }^{\circ} \mathrm{C}$ & $0.1075(0.0084)$ & $1.471(0.095)$ & $842(0.5)$ \\
$9 \% \mathrm{MC}, 200{ }^{\circ} \mathrm{C}$ & $0.3521(0.0262)$ & $1.638(0.062)$ & $769(1.1)$ \\
$9 \% \mathrm{MC}, 250{ }^{\circ} \mathrm{C}$ & $0.4333(0.1019)$ & $2.314(0.207)$ & $614(0.1)$ \\
$0 \% \mathrm{MC}, 150{ }^{\circ} \mathrm{C}$ & $0.3482(0.0241)$ & $1.627(0.051)$ & $893(3.8)$ \\
$0 \% \mathrm{MC}, 200{ }^{\circ} \mathrm{C}$ & $0.3398(0.0177)$ & $1.590(0.136)$ & $703(3.9)$ \\
$0 \% \mathrm{MC}, 250{ }^{\circ} \mathrm{C}$ & $0.3537(0.0340)$ & $1.736(0.253)$ & $607(0.1)$ \\
\hline
\end{tabular}

Standard deviation given in parenthesis

in increased wood compressibility (Hsu et al. 1988; Xiao et al. 2014). In the absence of moisture, the cell wall is more rigid and brittle and is easily crushed during hot pressing.

Figure 3 presents the sorption isotherms conducted at $20^{\circ} \mathrm{C}$ for control and hot-pressed samples. The maximum EMC at $20{ }^{\circ} \mathrm{C}$ and $90 \% \mathrm{RH}$ reaches $18 \%$, which is the range of that reported for hardwoods (Kolin and Janezic 1996; Navi and Girardet 2000). Hot pressing clearly decreases wood hygroscopicity, and the effect is more pronounced with the most severe hot-pressing conditions. These results corroborate previous observations for heat-treated wood (Kolin and Janezic 1996; Tabarsa and Chui 1997; Navi and Girardet 2000; Repellin and Guyonnet 2005). While at the lowest thermal treatment temperatures, the reduction of hygroscopicity is practically small, especially for oven-dry wood, it is again very marked when wood is hot-pressed at $250{ }^{\circ} \mathrm{C}$. For example, dry samples hot pressed at $250{ }^{\circ} \mathrm{C}$ equilibrate at ca. $10 \%$ EMC at an RH of $90 \%$, compared to $18 \%$ for control samples and $15-18 \%$ for samples hot-pressed at $150-200{ }^{\circ} \mathrm{C}$. This suggests a turning point in wood-water relationships when hot-pressing temperatures reach such high levels. Additionally, moist wood samples appear to be more affected by hot pressing than oven-dry samples (Fig. 3). This observation is in line with the findings of Navi and Girardet (2000), showing that steamed, hot-pressed wood exhibits a lower FSP and hygroscopicity than wood hot-pressed in the absence of steam. Such behavior has been explained on the basis of amorphous cellulose content and the propensity for cellulose to further crystallize when thermally activated in the presence of water (Kolin and Janezic 1996). Also, this reduction of wood hygroscpicity could be due to the disappearance or reduced accessibility of high-water-affinity functional groups, such as hydroxyl groups in wood polysaccharides. Almeida et al. (2009) indeed reported that hot pressing above $190{ }^{\circ} \mathrm{C}$ removed some hemicelluloses from the wood matrix and therefore reduced the amount of hydroxyl groups available for water binding. Hornification is also known to occur during heat treatment of wood; it involves the rearrangements of cellulose hydroxyl groups through irreversible microfibrils' bonding and stiffening of wood amorphous matrix after collapse of the pores in the cell wall. A recently proposed mechanism of the impact of hydroxyl group accessibility on wood MC might also be at play (Ratkauri et al. 2013). Namely, EMC decrease in heat-treated wood has been related to wood cell wall modulus (Hill et al. 2012; Rautkari et al. 2013; Borrega and Kärenlampi 2010).

\subsection{Effect of hot pressing on wood viscoelastic properties}

Temperature scans performed from room temperature to $120{ }^{\circ} \mathrm{C}$ showed a typical $E^{\prime}$ decrease with temperature for both control and hot-pressed samples, while a peak in $E^{\prime \prime}$ was observed around $50{ }^{\circ} \mathrm{C}$ (Fig. 4). No particular shift of this

Table 3 The oven-dry specific gravity and storage modulus $\left(E^{\prime}\right)$ and evaluation of statistical analysis at an $\alpha=0.05$ (with at least three replicates)

\begin{tabular}{|c|c|c|c|c|c|c|}
\hline \multirow[t]{2}{*}{ Treatment } & \multirow{2}{*}{$\begin{array}{l}\text { Oven-dry specific gravity }\left(\mathrm{SG}_{0, \mathrm{OD}}\right) \\
\text { Specific gravity }(\mathrm{SG})\end{array}$} & \multicolumn{2}{|c|}{$\begin{array}{l}\text { Storage modulus } \\
\left(E^{\prime}(\mathrm{GPa})\right)\end{array}$} & \multicolumn{2}{|c|}{$\begin{array}{l}\text { Specific storage modulus } \\
\left(\left(E^{\prime} / \mathrm{SG}_{0, \mathrm{OD}}\right)(\mathrm{GPa})\right)\end{array}$} & \multirow{2}{*}{$\begin{array}{l}E^{\prime} \text { decrease } \\
\left({ }^{\circ} \mathrm{C}\right)\end{array}$} \\
\hline & & $30{ }^{\circ} \mathrm{C}$ & $120^{\circ} \mathrm{C}$ & $30{ }^{\circ} \mathrm{C}$ & $120^{\circ} \mathrm{C}$ & \\
\hline Control & $0.35 \pm 0.03 \mathrm{C}$ & $5.7 \pm 1.6$ & $5.2 \pm 1.5$ & $16.4 \pm 6.1 \mathrm{~B}$ & $14.9 \pm 5.4 \mathrm{C}$ & $9 \pm 3$ \\
\hline $9 \%, 150{ }^{\circ} \mathrm{C}$ & $0.90 \pm 0.06 \mathrm{~A}$ & $28.2 \pm 5.8$ & $25.5 \pm 5.4$ & $31.7 \pm 7.1 \mathrm{~A}$ & $28.6 \pm 7.1 \mathrm{~A}$ & $10 \pm 2$ \\
\hline $9 \%, 200{ }^{\circ} \mathrm{C}$ & $0.90 \pm 0.06 \mathrm{~A}$ & $21.1 \pm 3.2$ & $19.6 \pm 3.1$ & $23.6 \pm 2.9$ A,B & $22.0 \pm 2.8 \mathrm{~A}, \mathrm{~B}, \mathrm{C}$ & $7 \pm 2$ \\
\hline $9 \%, 250{ }^{\circ} \mathrm{C}$ & $0.80 \pm 0.10 \mathrm{~A}, \mathrm{~B}$ & $21.9 \pm 4.5$ & $20.3 \pm 4.1$ & $27.6 \pm 5.1 \mathrm{~A}$ & $25.5 \pm 3.9 \mathrm{~A}, \mathrm{~B}$ & $7 \pm 2$ \\
\hline $0 \%, 150{ }^{\circ} \mathrm{C}$ & $0.64 \pm 0.16 \mathrm{~B}$ & $10.9 \pm 3.2$ & $10.3 \pm 3.0$ & $16.9 \pm 2.3 \mathrm{~B}$ & $16.0 \pm 2.4 \mathrm{C}$ & $6 \pm 2$ \\
\hline $0 \%, 200{ }^{\circ} \mathrm{C}$ & $0.85 \pm 0.12 \mathrm{~A}$ & $19.3 \pm 5.0$ & $17.1 \pm 5.3$ & $22.5 \pm 3.5 \mathrm{~A}, \mathrm{~B}$ & $19.8 \pm 4.0 \mathrm{~B}, \mathrm{C}$ & $12 \pm 8$ \\
\hline $0 \%, 250{ }^{\circ} \mathrm{C}$ & $0.80 \pm 0.05 \mathrm{~A}, \mathrm{~B}$ & $22.0 \pm 4.2$ & $20.7 \pm 3.9$ & $27.8 \pm 4.9 \mathrm{~A}$ & $26.1 \pm 4.5 \mathrm{~A}, \mathrm{~B}$ & $6 \pm 1$ \\
\hline ANOVA $p$ value & 0.0001 & - & - & 0.0001 & 0.0001 & 0.1417 \\
\hline \multirow[t]{2}{*}{ ANCOVA } & $p$ value (treatment) & 0.0038 & 0.0054 & - & - & - \\
\hline & $p$ value (SG) & 0.0015 & 0.0007 & - & - & - \\
\hline
\end{tabular}

ANCOVA analysis of covariance 


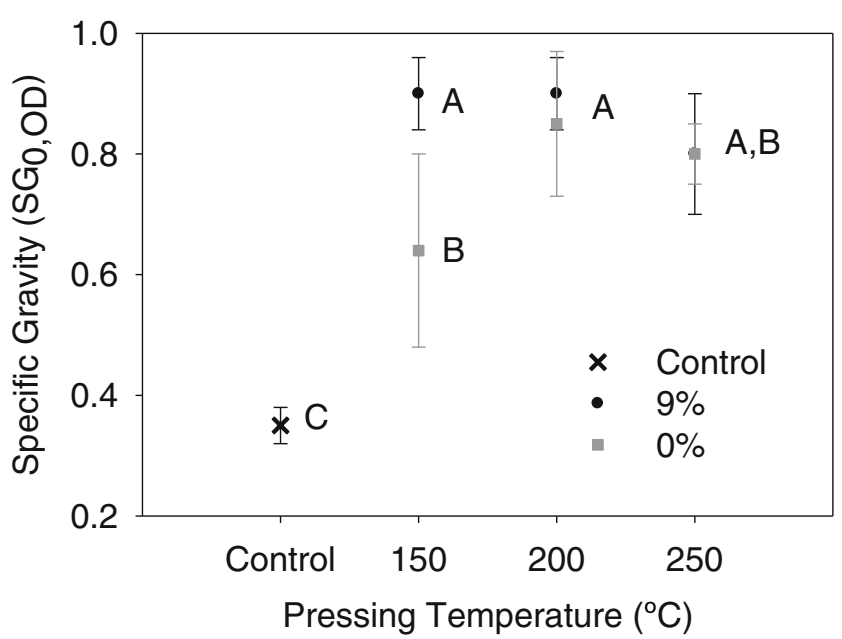

Fig. 2 Average specific gravity for control and hot-pressed hybrid poplar wood samples and its Tukey-Kramer grouping

relaxation temperature with hot-pressing treatment was observed ( $p=0.99$, Tables 3 and 4). Sugiyama et al. (1998) first reported a $\tan \delta$ peak $\left(\tan \delta=E^{\prime \prime} / E^{\prime}\right)$ around $75{ }^{\circ} \mathrm{C}$ on ovendried wood, which he ascribed to drying history. Using dielectric analysis, Jafarpous et al. (2008) similarly reported a relaxation peak around $39^{\circ} \mathrm{C}$ on dried poplar and cellulose powder and assigned it to the desorption of entrapped water. For absolutely dried specimens as in our study, Sun et al. (2007) also reported the onset of $\tan \delta$ peak between 75 and $150^{\circ} \mathrm{C}$, which they tentatively ascribed to the onset of hemicellulose glass transition temperature and determined to be extremely moisture sensitive, even between 0 and $0.7 \%$ MC. Here, the observed relaxation at $50{ }^{\circ} \mathrm{C}$ most likely reflects molecular motions from adsorbed water molecules.

To further evaluate the effect of hot pressing on wood viscoelastic properties, storage moduli at $30{ }^{\circ} \mathrm{C}\left(E^{\prime}\left(30{ }^{\circ} \mathrm{C}\right)\right)$

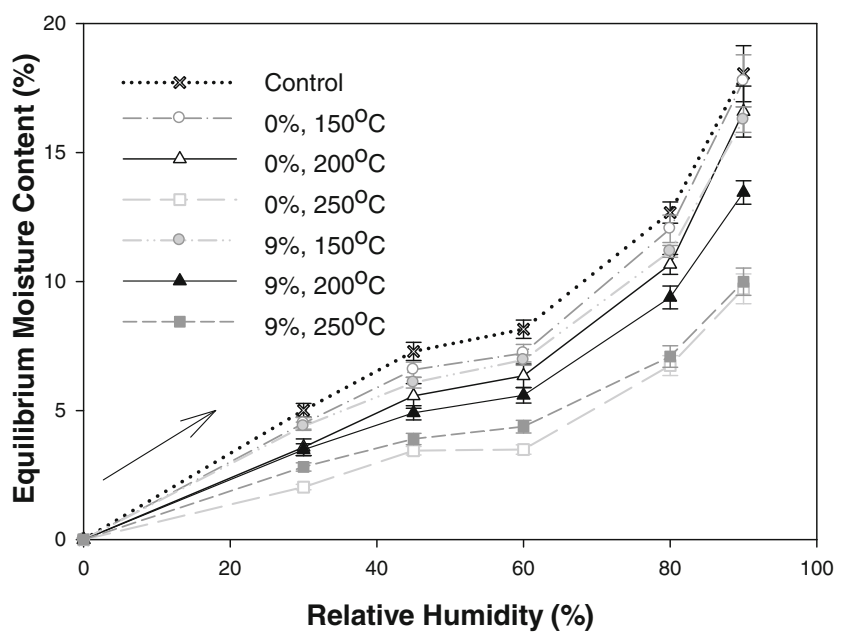

Fig. 3 Adsorption isotherms of control and hot-pressed hybrid poplar wood at $20^{\circ} \mathrm{C}$ (12 replicates each)
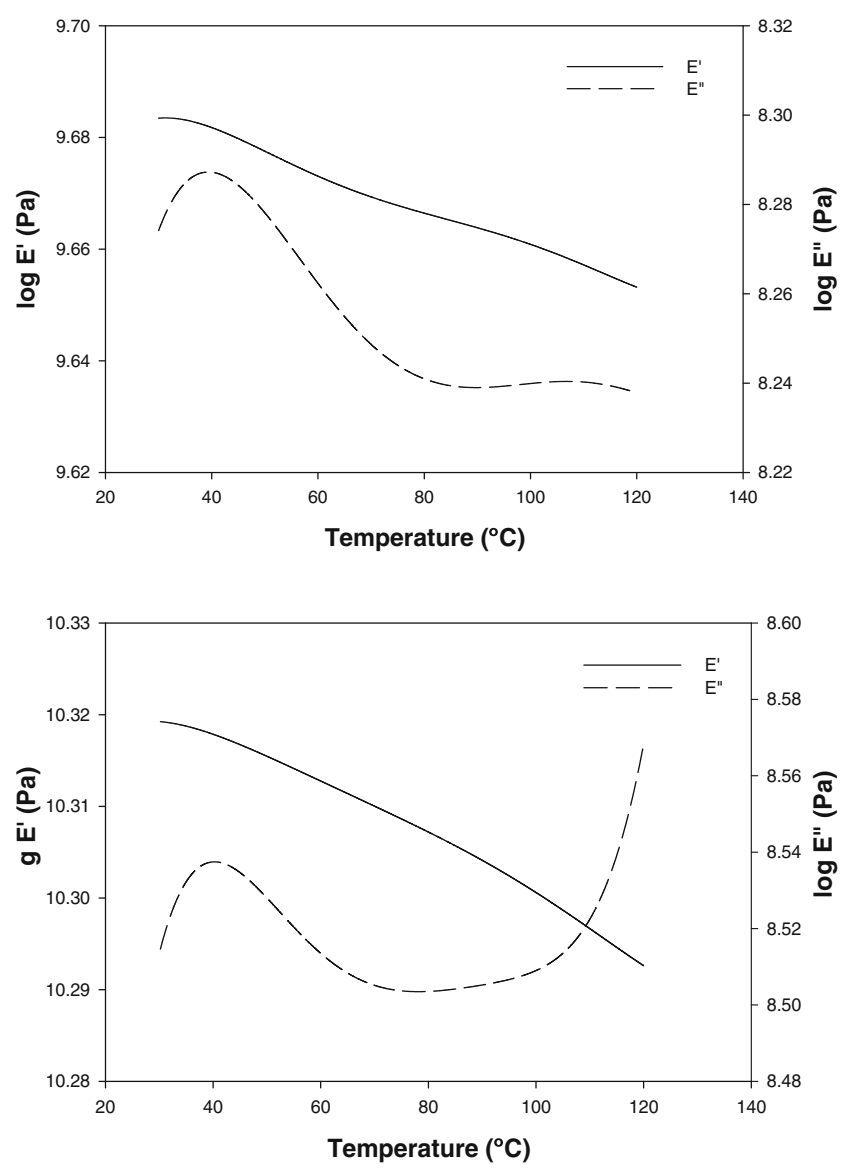

Fig. 4 Typical DMA temperature scan of hybrid poplar wood at $1 \mathrm{~Hz}$ utilizing $2{ }^{\circ} \mathrm{C} \mathrm{min}{ }^{-1}$ heating rate for control (top) and hot-pressed $(9 \%$ $\mathrm{MC}, 250^{\circ} \mathrm{C}$ ) hybrid poplar sample (bottom) tested in 3-point bending mode along the grain

and at $\left.120{ }^{\circ} \mathrm{C}\left(E_{(120}^{\prime}{ }^{\circ} \mathrm{C}\right)\right)$ were compared, along with the relative modulus drop over that temperature range,

$E_{\text {decrease }}^{\prime}(\%)=\frac{E_{\left(30{ }^{\circ} \mathrm{C}\right)}^{\prime}-E^{\prime}(120 \mathrm{C})}{E_{\left(30{ }^{\circ} \mathrm{C}\right)}^{\prime}} * 100$

Hot pressing appeared to increase the absolute value of both moduli (Fig. 5) in agreement with established relationships between wood mechanical properties and density (Bowyer et al. 2003). Figure 6 further reveals strong linear dependencies of storage modulus $\left(R^{2}=0.84\right)$ and loss modulus $\left(R_{E^{\prime}\left(30{ }^{\circ} \mathrm{C}\right)}^{2}=0.77\right.$ and $\left.R_{E^{\prime}\left(120{ }^{\circ} \mathrm{C}\right)}^{2}=0.91\right)$ on specific gravity at both 30 and $120^{\circ} \mathrm{C}$; that is, the large increase in dynamic moduli upon hot pressing can be largely explained by increases in specific gravity. In contrast, $E_{\text {decrease }}^{\prime}(\%)$ over the temperature range did not depend on specific gravity $\left(R^{2}=0.0125\right)$ or on the hot-pressing treatment ( $p$ value $=$ $0.1417)$.

To assess whether densification alone could explain the variations in $E^{\prime}$ and $E^{\prime \prime}$, ANCOVA was performed using specific gravity as a covariate. It evidenced no significant difference in loss moduli $\left(E^{\prime \prime}\left(30{ }^{\circ} \mathrm{C}\right) p\right.$ value $=0.54$ and 
Table 4 Oven-dry specific gravity of hot-pressed poplar, loss modulus $\left(E^{\prime \prime}\right)$ data, and evaluation of statistical analysis at an $\alpha=0.05$ (at least three replicates)

\begin{tabular}{|c|c|c|c|c|c|c|c|}
\hline \multirow[t]{2}{*}{ Treatment } & \multicolumn{2}{|c|}{ Oven-dry specific gravity $\left(\mathrm{SG}_{0, \mathrm{OD}}\right)$} & \multicolumn{2}{|c|}{ Loss modulus ( $\left.E^{\prime \prime}(\mathrm{GPa})\right)$} & \multicolumn{2}{|c|}{ Specific loss modulus ( $\left.E^{\prime \prime}(\mathrm{GPa})\right)$} & \multirow[t]{2}{*}{$E^{\prime \prime}$ peak $\left({ }^{\circ} \mathrm{C}\right)$} \\
\hline & & & $30{ }^{\circ} \mathrm{C}$ & $120^{\circ} \mathrm{C}$ & $30{ }^{\circ} \mathrm{C}$ & $120^{\circ} \mathrm{C}$ & \\
\hline Control & $0.35 \pm 0.03$ & $\mathrm{C}$ & $0.6 \pm 0.2$ & $0.5 \pm 0.2$ & $0.6 \pm 0.2$ & $0.5 \pm 0.2$ & $48 \pm 10$ \\
\hline $9 \%, 150{ }^{\circ} \mathrm{C}$ & $0.90 \pm 0.06$ & A & $0.6 \pm 0.1$ & $0.7 \pm 0.1$ & $0.6 \pm 0.1$ & $0.7 \pm 0.1$ & $47 \pm 4$ \\
\hline $9 \%, 200{ }^{\circ} \mathrm{C}$ & $0.90 \pm 0.06$ & A & $0.5 \pm 0.1$ & $0.6 \pm 0.1$ & $0.5 \pm 0.1$ & $0.6 \pm 0.1$ & $50 \pm 6$ \\
\hline $9 \%, 250{ }^{\circ} \mathrm{C}$ & $0.80 \pm 0.10$ & A,B & $0.5 \pm 0.3$ & $0.6 \pm 0.2$ & $0.5 \pm 0.3$ & $0.6 \pm 0.2$ & $50 \pm 10$ \\
\hline $0 \%, 150{ }^{\circ} \mathrm{C}$ & $0.64 \pm 0.16$ & $\mathrm{~B}$ & $0.4 \pm 0.1$ & $0.5 \pm 0.1$ & $0.4 \pm 0.1$ & $0.5 \pm 0.1$ & $48 \pm 3$ \\
\hline $0 \%, 200{ }^{\circ} \mathrm{C}$ & $0.85 \pm 0.12$ & A & $0.6 \pm 0.3$ & $0.6 \pm 0.2$ & $0.6 \pm 0.3$ & $0.6 \pm 0.2$ & $50 \pm 13$ \\
\hline $0 \%, 250{ }^{\circ} \mathrm{C}$ & $0.80 \pm 0.05$ & $\mathrm{~A}, \mathrm{~B}$ & $0.5 \pm 0.1$ & $0.5 \pm 0.1$ & $0.5 \pm 0.1$ & $0.5 \pm 0.1$ & - \\
\hline ANOVA $p$ value & 0.0001 & & - & - & 0.5220 & 0.7196 & 0.99 \\
\hline \multirow[t]{2}{*}{ ANCOVA } & \multicolumn{2}{|c|}{$p$ value (treatment) } & 0.5440 & 0.7794 & - & - & - \\
\hline & \multicolumn{2}{|c|}{$p$ value (SG) } & 0.0125 & 0.0058 & - & - & \\
\hline
\end{tabular}

Letters represent Tukey-Kramer grouping

ANCOVA analysis of covariance

$E^{\prime \prime}\left(120^{\circ} \mathrm{C}\right) \mathrm{p}$ value $\left.=0.78\right)$, besides density effect. Comparing the specific loss moduli $\left(s E^{\prime \prime}\right)$ with ANOVA $\left(s E^{\prime \prime}\left(30{ }^{\circ} \mathrm{C}\right)\right.$ $p$ value $=0.52$ and $s E^{\prime \prime}\left(120{ }^{\circ} \mathrm{C}\right) \quad p$ value $\left.=0.72\right)$ confirmed this conclusion (Table 3 ). On the other hand, over the temperature range tested, the hot-pressing treatment had an effect on $E^{\prime}\left(E_{(30}^{\prime}{ }^{\circ} \mathrm{C}\right) p$ value $=0.0038$ and $E_{\left(120{ }^{\circ} \mathrm{C}\right)}^{\prime} p$ value $\left.=0.0054\right)$, besides that of density (see Table 4). Expectedly then, the specific storage modulus for some hot-pressed samples differed significantly from that of control samples (ANOVA $p$ value $=0.0001)$. Specifically, the Tukey-Kramer grouping indicated that at both MCs, samples hot-pressed at $250{ }^{\circ} \mathrm{C}$ had higher specific storage moduli than control samples. All other hot-pressing conditions (at 150 and $200{ }^{\circ} \mathrm{C}$ ) resulted in

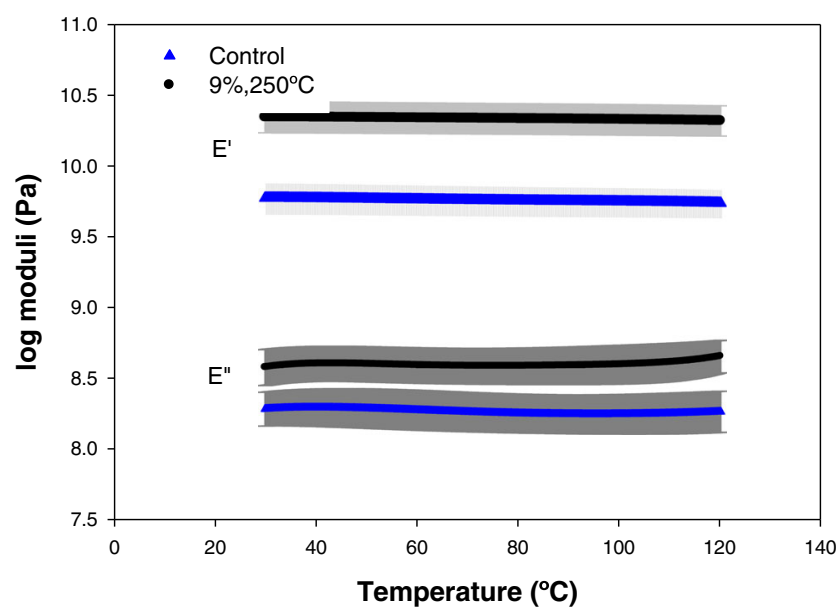

Fig. 5 Average storage $\left(E^{\prime}\right)$ and loss moduli $\left(E^{\prime \prime}\right)$ curves during a temperature scan for control and hot-pressed samples $\left(9 \% \mathrm{MC}, 250{ }^{\circ} \mathrm{C}\right)$ at $1 \mathrm{~Hz}$ with a $2{ }^{\circ} \mathrm{C} \min ^{-1}$ heating rate. Samples tested in 3-point bending mode along the grain with at least three replicates (with standard deviation) no change in specific storage moduli, except for the $9 \% \mathrm{MC}$ sample hot-pressed at $150{ }^{\circ} \mathrm{C}$, which appeared in many subsequent analyses to behave as an outlier. This finding coincides with results from a study investigating the effect of compressive strain and press temperature. Tabarsa and Chui (1997) found that differences in mechanical properties in hotpressed white spruce were small for pressing temperatures of 150 and $200{ }^{\circ} \mathrm{C}$ and wood $\mathrm{MC}$ of $15 \%$. The unique viscoelastic behavior of wood samples hot-pressed at $250{ }^{\circ} \mathrm{C}$ suggests again that a turning point in wood properties occurs over this hot-pressing temperature.

\section{Discussion on the molecular mechanism underlying changes in wood physical and viscoelastic properties during hot pressing}

The viscoelastic and hygroscopic changes observed in hybrid poplar during hot pressing are consistent with prior literature already evidencing increases in dynamic moduli, decreases in hygroscopicity and cellulose hydrolysis, and apparent crystallinity increase. Additionally, this study clearly establishes a turning point in wood behavior when hot-pressing temperature reaches $250{ }^{\circ} \mathrm{C}$. At this temperature, a change in the morphology of wood polymers may be expected. For example, an increase in stiffness might reflect cellulose crystallinity increases.

The statistical analyses of this study further demonstrate that the viscoelastic changes observed upon hot pressing relate, in part, not only to the degree of densification but also to other factors. Indeed, specific modulus was also found to be dependent on hot-pressing treatment. This effect was especially marked when reaching hot-pressing temperatures of 

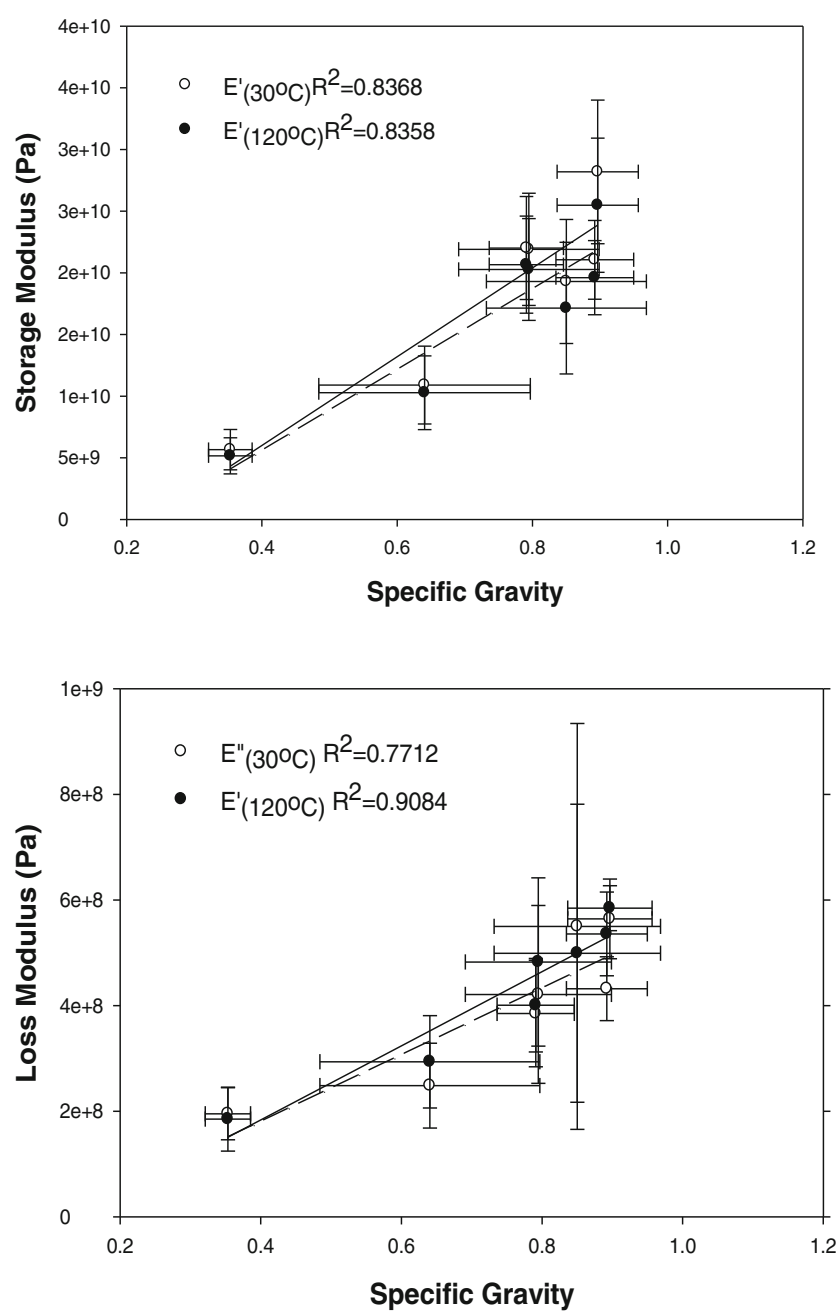

Fig. 6 Relationship between the storage modulus $\left(E^{\prime}\right)(s)$ or the drop in storage modulus $\left[\left(E^{\prime}{ }_{30}^{\circ}{ }^{\circ}-E^{\prime}{ }_{120}^{\circ} \mathrm{C}\right) / E^{\prime} 30{ }^{\circ} \mathrm{C} * 100\right]$ (middle and bottom) oven-dry specific gravity

$250{ }^{\circ} \mathrm{C}$. Molecular changes in wood constituents during hot pressing might well be determining factors or possible covariates of the viscoelastic changes observed as a result of hot pressing.

To further investigate whether the measured viscoelastic and hygroscopic properties could relate to wood molecular or morphological changes, attempts were made to relate viscoelastic properties with cellulose molecular parameters viz. apparent crystallinity index and $D P_{\mathrm{w}}$. Note that in these attempts, the dry sample hot-pressed at $150^{\circ} \mathrm{C}$ was not considered as it emerged as an outlier for all properties measured (Reiniati 2009). Hot pressing presumably did not properly function for this sample. Overall, the crystallinity determination using FTIR band height ratios of $H_{1,429} / H_{897}$ showed a direct relationship to the specific storage module (Fig. 7). As apparent crystallinity of cellulose increases, so does wood specific storage modulus. The linear regression analysis further indicates that the changes in cellulose apparent crystallinity explain ca. $60 \%$ of the variations in the specific storage modulus of hot-pressed wood (Fig. 7). An increase in the storage modulus could therefore be ascribed to an increase in cellulose crystallinity, especially at the most severe hot-pressing conditions and in the case of moist wood. Further exploration and insight into the molecular origin of wood specific moduli after hot pressing were sought by assessing relationships between specific storage moduli and cellulose $D P_{\mathrm{w}}$. Indeed, the data also clearly established an inverse linear relationship between cellulose in situ crystallinity index and cellulose $D P_{\mathrm{w}}$ (not shown). This relationship confirms that the apparent increases in crystallinity of cellulose stem in large part from hydrolysis and thus removal of cellulose amorphous regions. Interestingly, an even stronger linear correlation is evidenced between specific storage modulus and cellulose $D P_{\mathrm{w}}$. About $90 \%$ of the variation in the specific storage modulus in hot-pressed wood can be explained by variations in cellulose $D P_{\mathrm{w}}$. Such direct linear relationship has, to our knowledge, never been reported in hot-pressed wood; it clearly illustrates the high level of correlation between molecular changes in wood constituents and wood macroscopic properties. This behavior is consistent with previous reports on various wood species, which evidenced correlations between wood elastic strain under bending and cellulose crystal strain (Montero et al. 2012). Whether this strong correlation reflects a cause-effect relationship or is an incidental codependency cannot be
Fig. 7 Relationship between wood storage modulus $\left(E^{\prime}\right)$ and in situ cellulose properties, viz. apparent crystallinity index and degree of polymerization
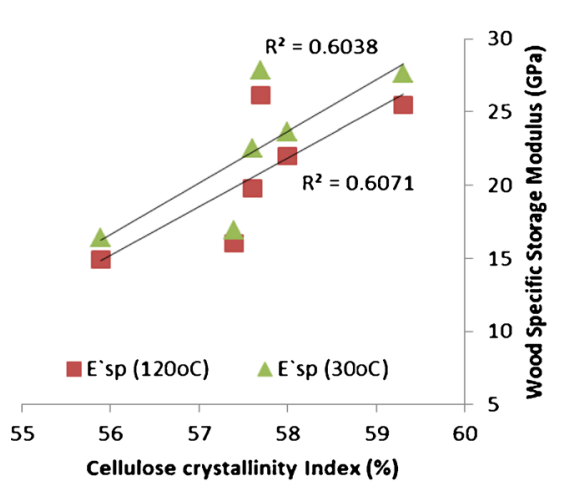

30

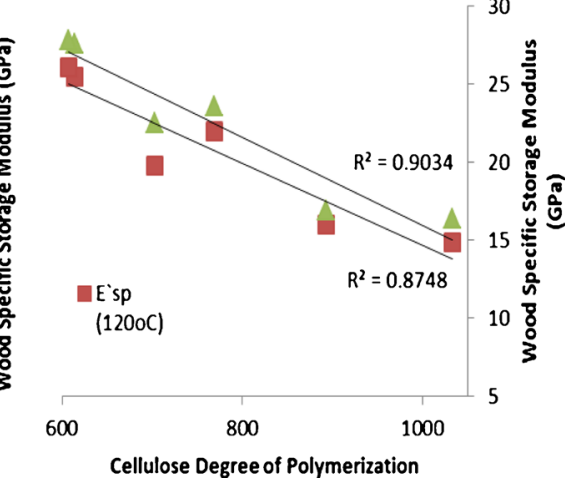


established on the sole basis of this analysis. However, clearly evidenced here are quantifiable parallel trends between a molecular parameter of wood polymeric constituent and a macroscopic property of bulk wood at various degrees of heat compression.

In addition to the changes occurring on wood carbohydrates, changes on lignin may play a role in alteration of wood hygroscopicity and viscoelasticity (Osman 2010; Xiao et al. 2014). Tjeerdsma et al. (1998) hypothesized that heat enhances the demethoxylation of guaiacyl and syringyl units in lignin, which increases the amount of reactive phenolic lignin sites available for reaction. Once the lignin demethoxylation and cross-linking of free phenolic units occur at approximately $220^{\circ} \mathrm{C}$, a more rigid structure forms around cellulose microfibrils and hinders water penetration in the cell wall (Tjeerdsma et al. 1998). Demethoxylation of lignin is likely to change its softening point and the resulting loss moduli properties. Lignin cross-linking and cellulose crystallinity increase both likely contribute to augment wood moduli, which is proposed to correlate with wood hygroscopicity (Hill et al. 2012). Further work on the viscoelastic properties of hot-pressed wood under plasticized conditions in relation to lignin molecular mobility is the topic of subsequent publication.

\section{Conclusions}

Hot pressing of hybrid poplar was found to significantly influence the specific gravity, dynamic mechanical properties, and hygroscopicity of the resulting hot-pressed wood. Specific storage modulus under bending was largely influenced by hot-pressing conditions, while loss modulus, drop in storage modulus with temperature, and wood polymer relaxation at ca. $50{ }^{\circ} \mathrm{C}$ were not affected. Cellulose in situ apparent crystallinity index was found to increase with hot-pressing severity, and this increase was accompanied with a $D P_{\mathrm{w}}$ decrease, evidencing hydrolysis and depolymerization of cellulose amorphous regions during hot pressing. While the changes in viscoelastic properties could be in large part ascribed to densification, covariate analysis along with the determination of specific viscoelastic properties allowed evidencing that factors other than density determined wood viscoelastic behavior. In particular, strong linear correlations between wood specific storage moduli on the one hand and apparent cellulose crystallinity (positive correlation with $R^{2}>0.6$ ) and cellulose $D P_{\mathrm{w}}$ (negative correlation, $R^{2}>0.9$ ) on the other hand were established. Direct correlations between the molecular parameters of wood constituents and resulting macroscopic behavior might not be of causal nature but do provide some molecular insight of wood property changes during hot pressing.
Acknowledgments The project was supported by the USDA-CSREES National Research Initiative grant number 2005-35103-15277 and USDA-CSREES Wood Utilization Research grant number 2008-3415819486. The authors are grateful to Dr. Karl Englund from Washington State University for support in statistical analyses.

Funding The project was supported by the USDA-CSREES National Research Initiative grant number 2005-35103-15277 and USDACSREES Wood Utilization Research grant number 2008-34158-19486.

\section{References}

Akerholm M, Hinterstoisser B, Salmen L (2004) Characterization of the crystalline structure of cellulose using static and dynamic FT-IR spectroscopy. Carbohydr Res 339:569-578

Akgúl M, Gúmúskaya E, Korkut S (2007) Crystalliné structure of heattreated scots pine [Pinus sylvestris L.] and Uludağ fin [ Abies nordmanniana (Stev.) subsp. bornmvelleriane (Matt f.)] wood, Wood Science Technology 41:281-289

Almeida G, Brito JO, Perre P (2009) Changes in wood-water relationship due to heat treatment assess on micro-samples of three Eucalyptus species. Holzforshung 66:80-88

Bhuyian MTR, Hirai N, Sobue N (2000) Changes of crystallinity in wood cellulose by heat treatment under dried and moist conditions. J Wood Sci 46:431-436

Borrega M, Kärenlampi P (2010) Hygroscopicity of heat-treated Norway spruce (Picea abies) wood. Eur J Wood Prod 68:233-235

Bowyer JL, Shmulsky R, Haygreen JG (2003) Forest products and wood science: an introduction, 4th edn. Blackwell, Ames

Cael JJ, Diggs AO, Cannon RE (1980) GPC and low angle laser light scattering for determination of cellulose molecular weight distributions. In: International Dissolving Pulps Conference (5th; 1980; Vienna), 216:216-223

Carrillo F, Colom X, Sunol JJ, Saurina J (2004) Structural FTIR analysis and thermal characterisation of lyocell and viscose-type fibres. Euro Polym J 40:2229-2234

Ferry JD (1980) Viscoelastic properties of polymers, 2nd edn. Wiley, New York

Gardner DJ, Gunnells DW, Wolcott MP, Amos L (1993) Changes in wood polymers during the pressing of wood-composites. In: Kennedy JF, Phillips GO, Williams PA (eds) Cellulosics, chemical, biochemical and material aspects. Ellis Horwood, New York, pp 513-518

Hakkou M, Petrissans M, El Bakali I, Gerardin P, Zoulalian A (2005a) Wettability changes and mass loss during heat treatment of wood. Holzforschung 59:35-37

Hakkou M, Petrissans M, Zoulalian A, Gerardin P (2005b) Investigation of wood wettability changes during heat treatment on the basis of chemical analysis. Polym Degrad Stabil 89:1-5

Hill C, Ramsay S, Keating B, Lain K, Rautkari L, Hughes M, Constant B (2012) The water vapour sorption properties of thermally modified and densified wood. J Mater Sci 47:31913197

Hsu WE, Schwald W, Schwald J, Shields JA (1988) Chemical and physical changes required for producing dimensionally stable wood-based composites. Part I: steam pretreatment. Wood Sci Technol 22:281-289

Ito Y, Tanahashi M, Shigematsu M, Shinoda Y (1998) Compressive molding of wood by high pressure steam treatment: Part 2: mechanism of permanent fixation. Holzforschung 52:217-221

Jafarpous G, Dantras E, Boudet A, Lacabanne C (2008) Molecular mobility of poplar cell wall polymers studied by dielectric techniques. J Non-Cryst Solids 354:3207-3214 
Kolin B, Janezic TS (1996) The effect of temperature, density, and chemical composition upon the limit of hygroscopicity of wood. Holzforschung 50:263-268

Korkut S, Akgul M, Dundar T (2008) The effects of heat treatment on some technological properties of Scots pine (Pinus sylvetris L.) wood. Bioresour Technol 99:1861-1868

Kotilainen R, Alen R, Arpiainen V (1999) Changes in the chemical composition of Norway spruce (Picea abies) at $160-260^{\circ} \mathrm{C}$ under nitrogen and air atmospheres. Paperi ja Puu 81:384-388

Kotilainen R, Alen R, Toivanen T (2001) Chemical changes in black alder (Alnus glutinosa) and European aspen (Populus tremula) during heating at $150-220^{\circ}$ in a nitrogen atmosphere. Cell Chem Technol 35:275-284

Laka M, Chernyavskaya S (2007) Obtaining microcrystalline cellulose from softwood and hardwood pulp. Bioresources 2:583-589

Montero C, Clair B, Almeras T, Van der Lee A, Gril J (2012) Relationship between wood elastic strain under bending and cellulose crystal strain. Comp Sci Technol 72:175-181

Navi P, Girardet F (2000) Effects of thermo-hydro-mechanical treatment on the structure and properties of wood. Holzforschung 54:287-293

Navi P, Heger F (2004) Combined densification and thermo-hydromechanical processing of wood. MRS Bull 29:332-336

Nelson ML, O'Connor RT (1964a) Relation of certain infrared bands to cellulose crystallinity and crystal lattice type. Part I. Spectra of lattice types I, II, III and of amorphous cellulose. J Appl Polym Sci 8:1311-1324

Nelson ML, O'Connor RT (1964b) Relation of certain infrared bands to cellulose crystallinity and crystal lattice type. Part II. A new infrared ratio for estimation of crystallinity in cellulose I and II. J Appl Polym Sci 8:1325-1341

Osman NB (2010) The chemistry of hot-pressing hybrid poplar wood. Dissertation, University of Idaho, Moscow, Idaho, USA

Osman NB, McDonald AG, Laborie M-PG (2012) Analysis of DCM extractable components from hot-pressed hybrid poplar. Holzforschung 66:927-934

Osman NB, Mc Donald AG, Laborie M-P (2013) Characterization of water-soluble extracts from hot-pressed poplar. Eur J Wood Prod 71: 343-351

Penneru AP, Jayaraman K, Bhattacharyya D (2006) Viscoelastic behavior of solid wood under compressive loading. Holzforschung 60: 294-298

Ratkauri L, Hill C, Curling S, Jalaludin Z, Ormondroyd G (2013) What is the role of the accessibility of wood hydroxyl groups in controlling moisture content? J Mater Sci 48:6352-6356
Reiniati I (2009) Chemical, physical, and viscoelastic properties of hotpressed hybrid poplar. Thesis, Washington State University, Pullman, Washington, USA

Reinprecht L, Kacik F, Solar R (1999) Relationship between the molecular structure and bending properties of the chemically and thermally degraded maplewood. Cellul Chem Technol 33:67-79

Repellin V, Guyonnet R (2005) Evaluation of a heat-treated wood solvent uptake by differential scanning calorimetry in relation to chemical composition. Holzforschung 59:28-34

Schroeder LR, Haigh FC (1979) Cellulose and wood pulp polysaccharides. Gel permeation chromatographic analysis. TAPPI J 62: 103-105

Silva MR, Machado GO, Brito JO, Calil Junior C (2013) Strength and stiffness of thermally rectified eucalyptus wood under compression. Math Res 16:1077-1083

Suckling ID, Allison RW, Campion SH, McGrouther KG, McDonald AG (2001) Monitoring cellulose degradation during conventional and modified kraft pulping. J Pulp Pap Sci 27:336-341

Sugiyama M, Obataya E, Norimoto M (1998) Viscoelastic properties of the matrix substance of chemically treated wood. J Mater Sci 33: 3505-3510

Sun N, Das S, Frazier CE (2007) Dynamic mechanical analysis of dry wood: linear viscoelastic response region and effects of minor moisture changes. Holforschung 66:28-33

Tabarsa T, Chui Y (1997) Effect of hot-pressing on properties of white spruce. For Prod J 47:71-76

Tjeerdsma BF, Boonstra M, Pizzi A, Tekely P, Militz H (1998) Characterization of thermally modified wood: molecular reasons for wood performance improvement. Holz Roh Werkst 56:149-153

Wise LE, Murphy M, D’Addieco AA (1946) Chlorite holocellulose: its fractionation and bearing on summative wood analysis and on studies on the hemicellulose. Pap Trade J 122:35-43

Wolcott MP, Kamke FA, Dillard DA (1990) Fundamentals of flakeboard manufacture: viscoelastic behavior of wood components. Wood Fiber Sci 22:345-361

Xiao L-P, Lin Z, Peng W-X, Yuan TQ, Xu F, Li NC, Tao QS, Xiang H, Sun RC (2014) Unraveling the structural characteristics of lignin in hydrothermal pretreated fibers and manufactured binderless boards from Eucalyptus grandis. Sust Chem Pro 2:9-21

Yildiz S, Gumuskaya E (2007) The effects of thermal modification on crystalline structure of cellulose in soft and hardwood. Build Envel 42:62-67

Yildiz UC, Yildiz S, Gezer ED (2005) Mechanical and chemical behavior of beech wood modified by heat. Wood Fiber Sci 37:456-461 